\title{
Prevalence of bovine trypanosomosis and its vectors in two districts of East Wollega Zone, Ethiopia
}

\begin{abstract}
Authors:
Wagari Tafese ${ }^{1}$

Achenef Melaku ${ }^{1}$

Tewodros Fentahun ${ }^{1}$

Affiliations:

${ }^{1}$ Faculty of Veterinary

Medicine, University of

Gondar, Ethiopia

Correspondence to:

Achenef Melaku

Email:

tbeyene11@gmail.com

Postal address:

PO Box 196, Gondar, Ethiopia

Dates:

Received: 27 Oct. 2011

Accepted: 06 Feb. 2012

Published: 15 May 2012

How to cite this article:

Tafese, W., Melaku, A.

\& Fentahun, T., 2012,

'Prevalence of bovine

trypanosomosis and its

vectors in two districts of

East Wollega Zone, Ethiopia',

Onderstepoort Journal of

Veterinary Research 79(1),

Art. \#385, 4 pages. http://

dx.doi.org/10.4102/ojvr.

v79i1.385
\end{abstract}

C 2012. The Authors. Licensee: AOSIS OpenJournals. This work is licensed under the Creative Commons Attribution License.
Trypanosomosis is a parasitic disease that causes serious economic losses in livestock, especially in sub-Saharan countries. This study was conducted from October 2010 to March 2011 in the Diga and Sasiga districts of the East Wollega zone in western Ethiopia to determine the prevalence of bovine trypanosomosis and its vectors. A total of 386 blood samples were collected from randomly selected animals. Packed cell volume (PCV) was determined and samples were examined for the presence of trypanosomes using the buffy coat technique. Out of 386 blood samples, $8.55 \%$ tested positive for trypanosomes. The majority of the infections were caused by Trypanosoma congolense (72.73\%), followed by Trypanosoma vivax $(27.27 \%)$. There were no statistically significant differences $(p>0.05)$ between districts, altitudes, sexes and ages, but the prevalence was significantly higher $(p<0.05)$ in cattle which were in poor body condition. The mean PCV value of infected animals (21.45 \pm 3.62 s.d.) was significantly lower $(p<0.05)$ than that of non-infected animals $(26.60 \pm 4.60$ s.d.). A total of 1151 flies were caught by deploying 21 monoconical shaped traps. Of these flies, $822(71.42 \%)$ were Glossina, whilst the remaining flies were either Stomoxys $(17.20 \%)$ or Tabanus $(11.38 \%)$. The overall apparent densities of tsetse and biting flies were 1.45 and 0.58 flies per trap per day, respectively. In conclusion, this study confirmed that trypanosomes and their vectors are prevalent and still pose a threat to cattle production in the area. Therefore, proper strategies have to be designed and implemented to minimise their effect on livestock production.

\section{Introduction}

Trypanosomosis is the main haemoparasitic disease in domestic animals and is caused by the protozoan parasite Trypanosoma. The parasite is transmitted biologically by the tsetse fly (Glossina species) and infects animals over an area known as the 'tsetse belt', which extends approximately 10 million $\mathrm{km}^{2}$ across 37 countries in Africa, from the Sahara Desert in the North to South Africa in the south (Ilemobade 2009; Marquardt, Demaree \& Grieue 2000; Parryet, Mabey \& Gill 2004). Some trypanosome species such as Trypanosoma vivax can be transmitted by biting flies mechanically and can establish itself even outside the tsetse belt, placing an estimated 160 million cattle and 260 million sheep and goats at risk (Leak 1996). Trypanosomosis in livestock causes great losses in terms of mortality, abortion, reduced fertility, milk and meat production, and ability to work as traction animals (Maudlin, Holmer \& Milor 2004). In addition to these, the disease is also responsible for an annual loss of millions of dollars in livestock production as a result of the cost related to treatment, prevention and vector control efforts (Samuel, Margo \& Kocan 2001).

In Ethiopia, the disease is more prevalent in the southern and western regions where the primary vector exists. Recently, however, new areas are being invaded and settled communities are being evicted continually by the advancing infections. Several attempts have been made to control trypanosomosis in the country, with chemotherapy and chemoprophylaxis being the most widely applied methods. Vector-targeted control practices have been implemented mainly through specifically designed joint projects of the Ministry of Agriculture and other non-governmental organisations. Knowing the current status of typanosomosis and its vectors are crucial to integrate all efforts towards combating the disease and reducing economic losses. Therefore, this study was conducted to determine the prevalence of bovine trypanosomosis in the Diga and Sasiga districts bordering Dhidhesa and Upper Anger river valley in the East Wollega zone of Ethiopia, as well as to identify vectors and their apparent density in the area.

\section{Materials and methods}

\section{Study area}

The study was carried out in the Diga and Sasiga districts of the East Wollega zone bordering Dhidhesa and the Anger valley river basin and their tributaries in western Ethiopia (Figure 1). The area has two seasons: rainfall from June to September and a dry season from October to May, with a mean annual rainfall of $1100 \mathrm{~mm}-1950 \mathrm{~mm}$. The altitude ranges from $1100 \mathrm{~m}$ a.s.l. 
- $2400 \mathrm{~m}$ a.s.l. The daily average minimum and maximum temperatures are $18.5^{\circ} \mathrm{C}$ and $27.5^{\circ} \mathrm{C}$, respectively (Central Statistical Agency 2010).

\section{Study animals}

The animals used in this study were local zebu cattle (Bos indicus), which are usually kept under an extensive husbandry system. Animals were allowed to graze freely during the day and housed in poorly constructed barns at night. The age of animals was determined by dentition (DeLahunta \& Hable 1986) and categorised into two age groups (adult and young). The body condition of animals was also grouped as 'good' or 'poor' based on criteria described by Nicholson and Butterworth (1986).

\section{Sample size determination}

A random sampling technique was used to recruit an animal for the study. The sample size was determined based on the formula given by Thrusfield (2005). Because there was no information about the prevalence of the disease in the area, $50 \%$ was taken as the expected prevalence and to calculate the sample size, $5 \%$ absolute precision and $95 \%$ confidence interval were also used. Therefore, the calculated sample size was 386.

\section{Parasitological study}

Blood sample collection was performed by piercing the marginal ear vein with a sterile lancet and blood was drawn by a heparinised capillary tube. After the first 24 samples were taken, the capillary tubes were centrifuged at $1200 \mathrm{rpm}$ for $5 \mathrm{~min}$ and the packed cell volume (PCV) was determined and recorded. The buffy coat was used for detection of trypanosome parasites and thin blood smears were prepared

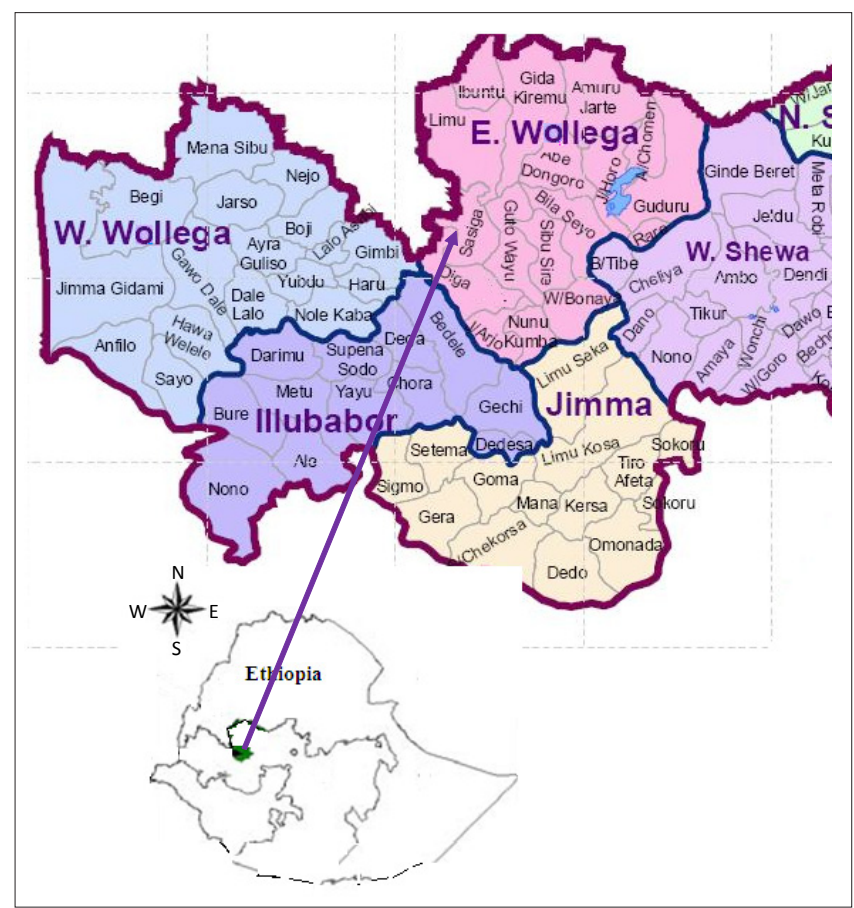

FIGURE 1: The map showing the location of the study area in western Ethiopia. from positive samples for species identification (Paris, Murray \& McOdimba 1982).

\section{Entomological survey}

The apparent densities of tsetse and biting flies were determined based on the mean fly catches in traps baited with acetone and cow's urine. A total of 21 traps with a monoconical shape were placed approximately $250 \mathrm{~m}$ apart and left in position for three consecutive days. The flies caught per trap were identified, counted and the apparent fly density per trap per day $(\mathrm{f} / \mathrm{t} / \mathrm{d}$ ) was recorded. This was repeated for three consecutive months (October, November and December). The tsetse flies were identified to species level and the other biting flies to the genus level (Marquardt et al. 2000).

\section{Statistical analysis}

Raw data were entered into a Microsoft Excel spreadsheet and descriptive statistics were used to summarise the data. The point prevalence was calculated for all data as the number of infected individuals divided by the number of individuals examined and multiplied by 100. The association between the prevalence of trypanosome infection and risk factors were assessed by logistic regression, whereas the student's $t$-test was used to assess the difference in mean PCV between trypanosome positive and negative animals. All statistical analyses were conducted using SPSS version 17.0 software (SPSS 2008). The test result was considered significant when the calculated $p$-value was less than 0.05 .

\section{Ethical considerations}

Ethical values were considered, starting from the approval of the proposal by the Faculty of Veterinary Medicine at the University of Gondar. The purpose of study was explained to the owner of the animals and permission was obtained. As a drop of blood was taken from the ear vein of the animals, they were not injured severely. The sampling sites were thoroughly disinfected before and after sampling. Animals were provided with adequate water and feed during the study by the owners, as usual.

\section{Results \\ Parasitological findings}

Thirty-three out of the total number of cattle examined (386), tested positive for trypanosome infection (8.55\%). Trypanosoma congolense was the dominant species identified $(72.73 \%)$ followed by $T$. vivax $(27.27 \%)$.

\section{Risk factors}

Risk factors such as district, altitude, age, sex and body condition score were assessed to know their relationship to the prevalence the disease (Table 1). The prevalence of trypanosomosis in the Diga and Sasiga districts was $10.00 \%$ and $7.97 \%$, respectively. However, there was no statistically significant difference $(p>0.05)$ between these 
two districts. The prevalence in female and male animals was $7.83 \%$ and $9.62 \%$, respectively; this difference was not statistically significant $(p>0.05)$. Of the 114 young and 272 adult animals examined, $8.77 \%$ and $8.46 \%$ tested positive for infection, respectively. This difference was also not significant $(p>0.05)$. However, the prevalence was significantly $(p<0.05)$ higher in animals in a poor body condition $(12.65 \%)$ than in those in good body condition (5.45\%). The prevalence was $8.76 \%$ and $8.15 \%$ in lowland and midland agro-climatic zones, respectively and this difference was not statistically significant $(p>0.05)$.

\section{Haematological findings}

The mean PCV value of infected animals (21.45 \pm 3.62 s.d.) was significantly lower $(p<0.05)$ than that of non-infected animals (26.60 \pm 4.60 s.d.).

\section{Entomological findings}

A total of 1151 flies were caught. Of these, 822 (71.42\%) belong to Glossina species, 198 (17.20\%) were Stomoxys and 131 (11.38\%) were Tabanus. Furthermore, all Glossina species caught were Glossina tachinoides. The overall apparent fly density was $2.03 \mathrm{f} / \mathrm{t} / \mathrm{d}$. The apparent density of Glossina, Stomoxys and Tabanus were $1.45 \mathrm{f} / \mathrm{t} / \mathrm{d}, 0.35 \mathrm{f} / \mathrm{t} / \mathrm{d}$ and $0.23 \mathrm{f} / \mathrm{t} / \mathrm{d}$, respectively.

\section{Discussion}

The overall prevalence of bovine trypanosomosis in the study area was $8.55 \%$, which is lower than previous reports: $12.41 \%$ in the Metekel and Awi zones of northwest Ethiopia (Solomon \& Fitta 2010), 20.40\% in the Wolyta and Dawero zones of southern Ethiopia (Miruk et al. 2008) and 20.9\% and $25.7 \%$ in the tsetse-free and the tsetse-infested zones of the Amhara region of north-western Ethiopia, respectively (Cherenet et al. 2006). The relatively low prevalence of trypanosomosis in this report may be related to tsetse distribution and low fly-animal contact. In addition, there were parasite and vector control programmes practiced in the area which might also have contributed to the low prevalence.

The prevalence of bovine trypanosomosis between the Diga and Sasiga districts was not significant. This may be the result of uncontrolled animal movements between districts. Amongst the trypanosome species, T. congolense (72.73\%) and T. vivax (27.27\%) were detected. A similar proportional trend was also reported by Mamoudou et al. (2006) and Solomon and Fitta (2010). Such a high ratio of T. congolense may be caused by the presence of a biological vector (Glossina), whereas T. vivax is more readily transmitted mechanically by biting flies than tsetse flies. The finding of this study was also in agreement with previous reports, in that only T. vivax was recovered in apparently tsetse-free areas (Cherenet et al. 2006). According to Abebe (2005), T. congolense and T. vivax are the most prevalent trypanosomes that infected cattle in the tsetse-infested and tsetse-free areas of Ethiopia, respectively.

The prevalence of bovine trypanosomosis was studied in different age and sex groups of cattle. Significant variation was not observed, which may be because of an equal chance of exposure to the parasite. Similar findings were also reported by Cherenet et al. (2006) and Habtamu (2009) in the Jawi district of the Amhara region, Ethiopia.

In this study, there was a significant difference in the prevalence of trypanosomosis between animals with 'good' and 'poor' body conditions, as well as between the mean PCV values of infected and non-infected animals. These two factors may be related to the debilitating nature of the disease (Radostits et al. 2007). In the absence of other diseases causing anaemia, a low PCV value of individual animals is a good indicator of trypanosome infection (Abebe 2005; Marcotty et al. 2008; Taylor, Coop \& Wall 2007).

The risk of trypanosomosis is also influenced by apparent density and types of vectors in the area. The apparent density of Glossina, Stomoxys and Tabanus were $1.45 \mathrm{f} / \mathrm{t} / \mathrm{d}, 0.35 \mathrm{f} / \mathrm{t} / \mathrm{d}$ and $0.23 \mathrm{f} / \mathrm{t} / \mathrm{d}$, respectively. This finding was lower than the report of Solomon and Fitta (2010), who reported $6.49 \mathrm{f} / \mathrm{t} / \mathrm{d}$ and $0.65 \mathrm{f} / \mathrm{t} / \mathrm{d}$ for tsetse and biting flies, respectively. The low level of tsetse population may be caused by the expansion of settlements and farmlands. It may also be related to the level of dryness, which resulted in the migration of game animals from the study area. The only species of tsetse fly identified in the area was Glossina tachnoid and this was also reported

TABLE 1: The prevalence of bovine trypanosomosis in relation to different risk factors examined in the study.

\begin{tabular}{|c|c|c|c|c|c|c|c|}
\hline \multirow[t]{3}{*}{ Risk factors } & \multirow[t]{3}{*}{ Categories } & \multirow{3}{*}{$\begin{array}{l}\text { Number of cattle } \\
\text { examined }\end{array}$} & \multirow{3}{*}{$\begin{array}{l}\text { Number of cattle } \\
\text { positive }\end{array}$} & \multicolumn{3}{|c|}{ Prevalence } & \multirow[t]{3}{*}{$p$-value } \\
\hline & & & & \multirow[t]{2}{*}{$\%$} & \multicolumn{2}{|c|}{$95 \% \mathrm{Cl}$} & \\
\hline & & & & & Lower & Upper & \\
\hline \multirow[t]{2}{*}{ Districts } & Diga & 110 & 11 & 10.00 & 4.39 & 15.61 & 0.260 \\
\hline & Sasiga & 276 & 22 & 7.97 & 4.78 & 11.17 & - \\
\hline \multirow[t]{2}{*}{ Sex } & Female & 230 & 18 & 7.83 & 4.35 & 11.30 & 0.270 \\
\hline & Male & 156 & 15 & 9.62 & 4.99 & 14.24 & - \\
\hline \multirow[t]{2}{*}{ Age } & Young & 114 & 10 & 8.77 & 3.58 & 13.96 & 0.460 \\
\hline & Adult & 272 & 23 & 8.46 & 5.15 & 11.76 & - \\
\hline \multirow[t]{2}{*}{ Body condition } & Good & 220 & 12 & 5.45 & 2.45 & 8.46 & 0.006 \\
\hline & Poor & 166 & 21 & 12.65 & 7.59 & 17.71 & - \\
\hline \multirow[t]{2}{*}{ Altitude } & Midland & 135 & 11 & 8.15 & 3.53 & 12.76 & 0.830 \\
\hline & Lowland & 251 & 22 & 8.76 & 5.27 & 12.26 & - \\
\hline
\end{tabular}

$\mathrm{Cl}$, confidence interval. 
by the National Tsetse and Trypanosomosis Investigation and Control Centre (2004).

\section{Conclusion}

In conclusion, this study indicated that trypanosomosis is an important disease in the Diga and Sasiga districts of the East Wollega zone in western Ethiopia. Appropriate strategies therefore have to be designed and implemented in this area to minimise the effect of the disease on livestock.

\section{Acknowledgements Competing interests}

The authors declare that they have no financial or personal relationship(s) which may have inappropriately influenced them in writing this paper.

\section{Authors' contributions}

A.M. (University of Gondar) was the project leader and designer in addition to editing and providing valuable comments on the manuscript. W.T. (University of Gondar) was responsible for data collection and draft preparation of the manuscript. T.F. (University of Gondar) made conceptual and editorial contributions and performed some statistical work.

\section{References}

Abebe, G., 2005, 'Trypanosomosis in Ethiopia', Ethiopian Journal of Biological Science $4(1), 75-123$.

Central Statistical Agency, 2010, Statistical abstracts: Agriculture and climate, CSA, Addis Ababa.

Cherenet, T., Sani, R.A., Speybroeck, N., Panandam, J.M., Nadzr, S. \& Van den Bossche, P., 2006, 'A comparative longitudinal study of bovine trypanosomiasis in tsetse-free and tsetse-infested zones of the Amhara region, northwest Ethiopia', Veterinary Parasitology 140, 251-258. http://dx.doi.org/10.1016/j. vetpar.2006.04.004, PMid:16675127
DeLahunta, A. \& Habel, R.E., 1986, 'Teeth', in A. DeLahunta \& R.E. Habel (eds.), Applied veterinary anatomy, n.p., W.B. Saunders Company, Philadelphia.

Habtamu, G., 2009, 'Current status of tsetse transmitted trypanosomes in Jawi district of Amhara region, north-west Ethiopia', DVM thesis, Faculty of Veterinary Medicine, Gondar University.

llemobade, A.A., 2009, 'Tsetse and trypanosomosis in Africa: The challenges, the opportunities', Onderstepoort Journal of Veterinary Research 76, 35-40.

Leak, S.G., 1996, 'The contribution to the epidemiology and understanding tsetse transmitted trypanosomiasis', PhD thesis, Universiteit Utrecht.

Mamoudou, A., Zoli, A., Mbahin, N., Tanenbe, C., Clausen, P.H., Marcotty, T. et al., 2006, 'Prevalence and incidence of bovine trypanosomosis on the Adamaoua plateau in Cameroon 10 years after the tsetse eradication campaign', Veterinary Parasitology 142, 16-22. http://dx.doi.org/10.1016/j.vetpar.2006.06.033, PMid:16887270

Marcotty, T., Simukoko, H., Berkvens, D., Vercruysse, J., Praet, N. \& Van Den Bossche, P., 2008, 'Evaluating the use of packed cell volume as an indicator of trypanosomal infections in cattle in eastern Zambia', Preventive Veterinary Medicine 87, 288300. http://dx.doi.org/10.1016/j.prevetmed.2008.05.002, PMid:18586340

Marquardt, W.C., Demaree, R.C. \& Grieue, R.B., 2000, Parasitology and vector biology, 2nd edn., Academic Press, London.

Maudlin, I.A., Holmer, P.H. \& Milor, M.A., 2004, The typanosomosis, Centre for Agricultural Bioscience International, Egham.

Miruk, A., Hagos, A., Yacob, H.T., Asnake, F. \& Basu, A.K., 2008, 'Prevalence of bovine trypanosomosis and trypanocidal drug sensitivity studies on Trypanosoma congolense in Wolyta and Dawero zones of southern Ethiopia', Veterinary Parasitology 152, 141-147. http://dx.doi.org/10.1016/j.vetpar.2007.12.007, PMid:18207329

National Tsetse and Trypanosomosis Investigation and Control Centre, 2004, NTTICC annual report: Bedelle, NTTICC, Addis Ababa.

Nicholson, M.J. \& Butterworth, M.H., 1986, A guide to scoring of zebu cattle, International Livestock Centre for Africa, Addis Ababa.

Paris, J., Murray, M. \& McOdimba, F., 1982, 'A comparative evaluation of the parasitological techniques currently available for the diagnosis of African trypanosomiasis in cattle', Acta Tropica 4, 307-316. PMid:6131590

Parryet, G.F., Mabey, R.D. \& Gill, F., 2004, Principles of medicine in Africa, Cambridge University Press, London.

Radostits, O.M., Blood, D.C., Gay, C.C., Hinchicliff, W.K. \& Constable, P.D., 2007 Veterinary medicine. A textbook of the diseases of cattle, sheep, pigs, goats and horses, 10th edn., Saunders Ltd, Edinburgh.

Samuel, W.M., Margo, J.P. \& Kocan, A.A., 2001, Parasitic diseases of wild mammals, 4th edn., Blackwell Publishing Company, Malden.

Solomon, M. \& Fitta, G., 2010, 'Survey on bovine trypanosomosis and its vector in Metekel and Awi zones of northwest Ethiopia', Acta Tropica 117(2011), 146-151. http://dx.doi.org/10.1016/j.actatropica.2010.11.009, PMid:21110937

SPSS version 17.0, 2008, computer software, SPSS Inc., Chicago.

Taylor, M.A., Coop, R.L. \& Wall, R.L., 2007, Veterinary parasitology. 3rd edn., Blackwell Publishing Company, Oxford.

Thrusfield, M., 2005, Veterinary epidemiology. 3rd ed., Wiley-Blackwell, Philadelphia. 